\title{
The final pathogenetic steps in focal bone erosions in rheumatoid arthritis
}

\author{
Steven R Goldring
}

The presence of peri-articular osteoporosis and focal bone erosions at the joint margins and within the subchondral bone adjacent to inflamed joints has been considered the radiographic hallmark of rheumatoid arthritis (RA).${ }^{1-4}$ In addition, in recent years there has been an increased awareness that RA also produces adverse effects on systemic bone remodelling at sites not directly involved with joint inflammation. Numerous reports have documented that people with RA have reduced axial and appendicular bone mass and that this bone loss is associated with an increased risk of fracture. ${ }^{5-11}$ Thus, it is possible to identify three distinct patterns of bone loss in RA. These include systemic osteoporosis, juxta-articular osteopenia adjacent to inflamed joints and focal marginal and subchondral bone erosions that are associated directly with inflamed synovial tissues. Each of these disorders represents an example of disturbed skeletal tissue remodelling in which there is a net loss of bone, although the precise mechanisms responsible for the bone loss in each of these conditions may involve differential cellular and regulatory processes. This review will focus on the mechanisms involved in the pathogenesis of focal bone erosions that are directly associated with the inflammatory synovial lesion.

Insights into the processes underlying the development of focal bone erosions in RA have been derived principally from histopathological evaluation of joint tissues from patients with RA and from animal models of inflammatory arthritis. Early studies by Bromley and Woolley demonstrated the presence of multinucleated cells with phenotypic features of osteoclasts in resorption lacunae at the pannus-bone interface. ${ }^{12-14}$ More recently, in our own studies, ${ }^{15}$ we have used in situ hybridisation to demonstrate that multinucleate and some mononuclear cells in resorption lacunae at the bone-pannus interface exhibit the entire repertoire of phenotypic markers that are associated with the fully differentiated osteoclast. This includes the expression of cathepsin $\mathrm{K}$, tartrate resistant acid phosphatase and the calcitonin receptor. Observations in animal models of collagen induced and adjuvant arthritis have also indicated that cells with phenotypic features of osteoclasts are present in resorption bays at sites of focal bone resorption. ${ }^{16}{ }^{17}$ The demonstration that marginal joint and subchondral bone erosions are mediated by osteoclasts has significant implications with respect to the development of strategies to directly and specifically target these cells or the regulatory pathways that control their recruit- ment and differentiation to prevent focal bone erosions in RA.

Despite the evidence that cells with phenotypic features of osteoclasts can be found at sites of focal bone erosions at the bone-pannus interface, there remains some controversy regarding the capacity of other cell types present within the rheumatoid synovium, such as activated macrophages or synovial fibroblasts, to degrade the mineralised bone matrix. ${ }^{18}$ Several lines of evidence, however, suggest that these cells have a limited capacity to resorb bone compared with authentic osteoclasts. For example, Hatterleys and Chambers $^{19} 20$ examined the capacity of osteoclast precursors generated in bone marrow cultures to resorb bone matrix. In this system, marrow derived cells of monocyte-macrophage lineage were induced to differentiate into osteoclasts. They demonstrated that the unique resorbing capacity of the osteoclasts generated in these cultures was expressed very late in the differentiation cascade and that the expression of tartrate resistant acid phosphatase and multinuclearity were poor indicators of the ability of cells to resorb bone. The unique capacity of the osteoclast-like cells to resorb bone coincided with the expression of the calcitonin receptor. We have made similar observations in our own studies of calcitonin receptor regulation. ${ }^{21}$ This receptor binds the peptide hormone calcitonin leading to the inhibition of osteoclast mediated bone resorption. ${ }^{22}{ }^{23}$ The demonstration of calcitonin receptor expression in osteoclast-like cells at the bone-pannus interface thus provides evidence that these cells are functionally mature osteoclasts with full bone resorbing potential.

Further compelling evidence that osteoclasts are the principal cell types responsible for the erosions at the bone-pannus interface is suggested by the recent observations of Kong et $a l .^{24}$ They investigated the effects of a newly identified potent inhibitor of osteoclast differentiation and activity, osteoprotegerin (OPG), on the development of cortical and trabecular bone erosions in the rat model of adjuvant arthritis. OPG is a member of the tumour necrosis factor (TNF) receptor family and acts as a decoy receptor to bind a novel factor that has been shown, based on targeted gene knock out studies, to be an essential factor required for osteoclast differentiation. ${ }^{25}{ }^{26}$ This osteoclast differentiation factor, which has been variously identified as ODF, RANK ligand (RANKL), and osteoprotegerin ligand (OPGL), is a member of the TNF-ligand family of cytokines, and regulates osteoclast differentiation and activity through binding to its 
receptor, RANK (receptor activator of NF- $\mathrm{KB}$ ) on osteoclast precursors. ${ }^{27}{ }^{28}$ Of interest, it was originally cloned as a product of activated $\mathrm{T}$ cells and was identified as TNF related activation induced cytokine (TRANCE). ${ }^{29}{ }^{30}$ Kong et $a l^{24}$ showed that treatment of rats with adjuvant arthritis with OPG almost completely abolished the development of focal bone erosions. Examination of the inflamed synovial tissue demonstrated that the OPG treatment had minimal effect on synovial inflammation but there was a marked reduction in osteoclast number at the interface between the bone and synovium. Thus, despite the presence of activated macrophages and synovial fibroblasts, in the absence of osteoclasts there was almost complete inhibition of bone loss. These findings, although limited to an animal model of arthritis, provide the most convincing evidence that osteoclasts are the principal cell type required for focal bone resorption in inflammatory arthritis.

In the studies by Kong and more recently by our group and others, human synovial fibroblasts, as well as CD4+ and CD8+ $\mathrm{T}$ lymphocytes, from RA synovium and synovial fluids have been shown to express RANKL/ ODF. ${ }^{243132}$ Direct evidence that synovial fibroblasts can support osteoclast formation that is at least in part dependent on RANKL/ODF is provided by the studies of Takayanagi et $a l^{33}$ who showed that RA synovial fibroblasts could induce osteoclast-like cells when cocultured with peripheral blood mononuclear cells. A direct role for $\mathrm{T}$ cell regulation of osteoclastogenesis is provided by studies demonstrating that activated $\mathrm{T}$ cells support osteoclast formation from haematopoietic precursors in the absence of osteoblast/stromal cells. ${ }^{24}{ }^{32}$ Despite these compelling data indicating a role for RANKL/ODF in the pathogenesis of focal bone erosions in RA, further studies are necessary to prove that this factor plays a primary part in this process. The data thus far indicate that RANKL/ODF activity is essential for osteoclast mediated bone resorption, but this does not prove that RANKL/ODF is the factor directly responsible for the increased osteoclast formation and activity in inflammatory forms of arthritis.

In addition to RANKL/ODF, RA synovium produces a wide variety of cytokines and other products involved in the regulation of osteoclast differentiation and activity. These include interleukin $1 \alpha$ and $\beta$ (IL1 $\alpha$ and IL1 $\beta$ ), interleukin 6 , interleukin 11 , monocyte colony stimulating factor, $\mathrm{TNF} \alpha$ and parathyroid related protein, which is the factor responsible for humoral hypercalcaemia of malignancy. ${ }^{34-38}$ The results from recent clinical trials in patients with RA treated with agents that specifically target IL 1 or $T N F \alpha$ provide the most compelling evidence that these cytokines play a part in the pathogenesis of focal bone erosions. ${ }^{39}{ }^{40}$ These studies indicate that interference with the activity of these cytokine can retard or even prevent the progression of focal bone erosions in RA subjects. However, it is difficult to differentiate the effects of these treatments on reduction in synovial inflamma- tion from possible direct effects on osteoclast differentiation or activity. Additional insights are provided by analysis of the effects of anticytokine treatment in animal models of arthritis. Of interest, these studies indicate that although inhibition of TNF or IL1 activity reduce the synovial inflammation in the murine collagen induced arthritis model, only IL1 blockade prevents the development of bone erosions. ${ }^{41} 42$

In considering the optimal treatment regimen for RA, the ultimate goal would be the development of a therapeutic approach that could halt or prevent the progression of the inflammatory synovial lesion. Until recently, although it has been possible to demonstrate amelioration in clinical symptoms and improvement in certain laboratory parameters of inflammation, there has been limited evidence that the treatments prevented progressive cartilage and focal articular bone loss. However, several recent studies have shown that certain treatment regimens, including those that specifically block the activities of IL1 and TNF, can retard or in some cases prevent the development of focal bone erosions. ${ }^{39}{ }^{43-46}$ In addition to these approaches that target the proliferative synovial lesion, it is reasonable to consider treatments that are directed specifically at the pathological processes associated with the pathogenesis of focal bone and cartilage destruction. The demonstration that osteoclasts mediate a component of the focal bone destruction at the bone-pannus interface suggests that treatments directed at blocking osteoclast differentiation or activity could prevent or retard the progression of bone erosions. The best support for the efficacy of this approach is derived from the demonstrated in an rat model of adjuvant arthritis the capacity of OPG, the decoy receptor for the potent osteoclast differentiation factor, RANKL/ ODF, to block osteoclast mediated bone erosions. ${ }^{24}$ In patients with RA, trials with bisphosphonates or calcitonin, which have been shown to inhibit osteoclast mediated bone resorption, did not prevent the progression of focal bone erosions, although they did have a beneficial effect on systemic osteoporosis. ${ }^{47-49}$ In contrast, there is evidence from studies in animal models of inflammatory arthritis that certain regimens with bisphosphonates may retard or prevent the development of focal bone erosions. Until uniformly effective treatments are available that can successfully prevent or halt the progression of both the synovial inflammation and focal bone destruction in RA, it is reasonable to further explore the possibility of parallel treatment approaches that specifically target osteoclast mediated bone resorption in people with RA.

\footnotetext{
1 Goldring SR, Polisson RP. Bone disease in rheumatological disorders. In: Avioli L, Krane SM, eds. Metabolic bone disease 2nd ed. San Diego: Academic Press, 1998: 621-35. Goldring SR, Goldring MB. Rheumatoid arthritis and other inflammatory joint pathologies. Siebel MJ, Robin SP, Bilezikian JP, eds. Dynamics of bone and cartild

3 Goldring SR, Gravallese EM. Mechanisms of bone loss in inflammatory arthritis: diagnosis and therapeutic implications. Arthritis Res 2000;2:33-7.
} 
4 Goldring SR, Gravallese EM. Pathogenesis of bone erosions in rheumatoid arthritis. Curr Opin Rheumatol 2000;12: in rheu.

5 Sambrook P, Ansel B, Foster S, Gumpel JM, Hesp R, Reeve $\mathrm{J}$. Bone turnover in early rheumatoid arthritis; longitudinal bone density studies. Ann Rheum Dis 1985;44:580-4

6 Sambrook PN, Eisman JA, Yeates MG, Pocock NA, Eberl S, Champion GD. Osteoporosis in rheumatoid arthritis: safety of low dose corticosteroids. Ann Rheum Dis 1986;45:950-3

7 Sambrook PN, Eisman A, Champion G, Yeates MG, Pocock NA, Eberl S. Determinants of axial bone loss in rheumatoid arthritis. Arthritis Rheum 1987;30:721-8.

8 Deodhar AA, Woolf AD. Bone mass measurement and bone metabolism in rheumatoid arthritis: a review. Br J Rheumatol 1996;35:309-22.

9 Gough AK, Peel NF, Eastell R, Holder RL, Lilley J, Emery P. Excretion of pyridinium crosslinks correlates with disease activity and appendicular bone loss in early disease activity and appendicular bone loss in earty

10 Hooyman JR, Melton U, Nelson AM, O'Fallon WM, Riggs BL. Fractures after rheumatoid arthritis; a population BL. Fractures after rheumatoid arthritis; a p
based study. Arthritis Rheum 1984;27:1353-61.

11 Haugeberg G, Uhlig T, Falch JA, Halse JI, Kvien TK. Bone mineral density and frequency of osteoporosis in female patients with rheumatoid arthritis: results from 394 patients in the Oslo County Rheumatoid Arthritis Register. Arthritis Rheum 2000;43:522-30.

12 Bromley M, Woolley DE. Chondroclasts and osteoclasts at subchondral sites of erosion in the rheumatoid joint. Arthritis Rheum 1984;27:968-75.

13 Bromley M, Fisher WD, Woolley DE. Mast cells at sites of cartilage erosion in the rheumatoid joint. Ann Rheum Dis 1984;43:76-9.

14 Bromley M, Woolley DE. Histopathology of the rheumatoid lesion. Identification of cell types at sites of cartilage erosion. Arthritis Rheum 1984;27:857-63.

15 Gravallese EM, Harada Y, Wang JT, Gorn AH, Thornhill TS, Goldring SR. Identification of cell types responsible for bone resorption in rheumatoid arthritis and juvenile rheumatoid arthritis. Am J Pathol 1998;152:943-51.

16 Romas E, Bakharevski O, Hards, DK, Kartsogiannis V, Quinn JMW, Ryan PFJ, et al. Expression of osteoclast differentiation factor at sites of bone erosion in collageninduced arthritis. Arthritis Rheum 2000;43:821-6.

17 Kuratani T, Nagata K, Kukita T, Hotokebuchi T, Nakasima A, Iijima, T. Induction of abundant osteoclast-like multinucleated giant cells in adjuvant arthritic rats with accompanying disordered high bone turnover. Histol Histopatho 1998;13:751-9.

18 Hummel KM, Petrow PK, Franz JK, Muller-Ladner U, Aicher WK, Gay RE, et al. Cysteine proteinase cathepsin K mRNA is expressed in synovium of patients with rheumatoid arthritis and is detected at sites of synovial bone destruction. J Rheumatol 1998;25:1887-94.

19 Hattersley G, Chambers TJ. Calcitonin receptors as markers for osteoclastic differentiation: correlation between generation of bone-resorptive cells and cells that express calcitonin receptors in mouse bone marrow express calcitonin receptors in mouse

20 Hattersley G, Chambers TJ. Generation of osteoclastic function in mouse bone marrow cultures: multinuclearity and tartrate-resistant acid phosphatase are unreliable markers for osteoclastic differentiation. Endocrinology 1989;124:1689-96

21 Lee SK, Goldring SR, Lorenzo JA. Expression of the calcitonin receptor in bone marrow cell cultures and in bone: a specific marker of the differentiated osteoclast that is regulated by calcitonin. Endocrinology 1995;136:45 72-81.

22 Yamin M, Gorn AH, Flannery MP, Jenkins NA, Gilbert DJ, Copeland NG, et al. Cloning and characterization of a mouse brain calcitonin receptor complementary deoxyribonucleic acid and mapping of the calcitonin receptor gene. Endocrinology 1994; 135:2635-43.

23 Gorn AH, Rudolph SM, Flannery MR, Morton CC, Weremowicz S, Wang J-T, et al. Expression of two human skeletal calcitonin receptor isoforms cloned from a giant cell tumor of bone. J Clin Invest 1995;95:2680-91.

24 Kong YY, Feige U, Sarosi I, Bolon B, Tafuri A, Morony S, $e$ al. Activated $\mathrm{T}$ cells regulate bone loss and joint destruction in adjuvant arthritis through osteoprotegerin ligand. Nature 1999;402:304-9.

25 Simonet WS, Lacey DL, Dunstan CR, Kelley M, Chang MS, Luthy R, et al. Osteoprotegerin: a novel secreted protein involved in the regulation of bone density. Cell 1997;89:309-19

26 Yasuda H, Shima N, Nakagawa N, Mochizuki SI, Yano K, Fujise $\mathrm{N}$, et al. Identity of osteoclastogenesis inhibitory factor (OCIF) and osteoprotegerin (OPG): a mechanism by which OPG/OCIF inhibits osteoclastogenesis in vitro. Endocrinology 1998;139:1329-37.

27 Yasuda H, Shima N, Nakagawa N, Yamaguchi K, Kinosaki $\mathrm{M}$, Mochizuki SI, et al. Osteoclast differentiation factor is a ligand for osteoprotegerin/osteoclastogenesis-inhibitory factor and is identical to TRANCE/RANKL. Proc Nat Acad Sci USA 1998;95:3597-602.

28 Lacey DL, Timms E, Tan HL, Kelley MJ, Dunstan CR, Burgess $\mathrm{T}$, et al. Osteoprotegerin ligand is a cytokine that regulates osteoclast differentiation and activation. Cell 1998;93:165-76.

29 Wong BR, Josien R, Lee SY, Sauter B, Li HL, Steinman RM, et al. TRANCE (tumor necrosis factor [TNF]-related activation-induced cytokine), a new TNF family member predominantly expressed in $\mathrm{T}$ cells, is a dendritic cell-specific survival factor. J Exp Med 1997;186:2075-80.

30 Wong BR, Rho J, Arron J, Robinson E, Orlinick J, Chao M, et al. TRANCE is a novel ligand of the tumor necrosis facT cells. J Biol Chem 1997;272:25190-4.

31 Gravallese EM, Manning C, Tsay A, Naito A, Pan C, Amento E, et al. Synovial tissue in rheumatoid arthritis is a source of osteoclast differentiation factor. Arthritis Rheum 2000;43:250-8.

32 Horwood NJ, Kartsogiannis V, Quinn JMW, Romas E, Martin U, Gillespie MT. Activated T lymphocytes support osteoclast formation in vitro. Biochem Biophys Res Commun 1999;265:144-50.

33 Takayanagi H, Izuka H, Juji T, Nakagawa T, Yamamoto A, Miyazaki $\mathrm{T}$, et al. Involvement of receptor activator of nuclear factor kappa-B ligand/osteoclast differentiation factor in osteoclastogenesis from synoviocytes in rheumatoid arthritis. Arthritis Rheum 2000; 43:259-69.

34 Chu CQ, Field M, Allard S, Abney E, Feldmann M, Maini $\mathrm{RN}$. Detection of cytokines at the cartilage/pannus junction in patients with rheumatoid arthritis: implications for the role of cytokines in cartilage destruction and repair. $\mathrm{Br} \mathrm{J}$ Rheumatol 1992;31:653-61.

35 Feldmann M, Brennan FM, Maini RN. Role of cytokines in rheumatoid arthritis. Ann Rev Immunol 1996;14:397-440.

36 Deleuran BW, Chu CQ, Field M, Brennan FM, Katsikis P, Feldmann M, et al. Localization of interleukin-1 alpha, type 1 interleukin-1 receptor and interleukin-1 receptor antagonist in the synovial membrane and cartilage/pannus
junction in rheumatoid arthritis. Br J Rheumatol 1992;31: 801-9.

37 Funk JL, Cordaro LA, Wei H, Benjamin JB, Yocum DE. Synovium as a source of increased amino-terminal parathyroid hormone-related protein expression in rheumatoid arthritis; a possible role for locally produced parathyroid hormone-related protein in the pathogenesis of rheumatoid arthritis. J Clin Invest 1998; 101: 1362-71.

38 Okano K, Tsukazaki T, Ohtsuru A, Namba H, Osaki M, Iwasaki $\mathrm{K}$, et al. Parathyroid hormone-related peptide in synovial fluid and disease activity of rheumatoid arthritis. Br J Rheumatol 1996;35:1056-62.

39 Bresnihan B, Alvaro-Gracia JM, Cobby M, Doherty M, DomIjan Z, Emery P, et al. Treatment of rheumatoid arthritis with recombinant human interleukin-1 receptor antagonist. Arthritis Rheum 1998;41:2196-204.

40 Finck B, Martin R, Fleischmann R, Moreland L, Schiff M, Bathon J. A phase III trial of etanercept vs methotrexate (MTX) in early rheumatoid arthritis (En

41 Joosten LAB, Helsen MMA, van de Loo FAJ, van den Berg WB. Anticytokine treatment of established type II collageninduced arthritis in DBA/ 1 mice; a comparative study using anti-TNF alpha, anti- IL-1 alpha/beta, and IL-1Ra. Arthritis Rheum 1996;39:797-809.

42 Joosten LAB, Helsen MMA, Saxne T, Heinegard D, van de Putte LB, van den Berg WB. Synergistic protection against cartilage destruction by low dose prednisolone and interleukin-10 in established murine collagen arthritis. Inflamm Res 1999;48:48-55.

43 Moreland LW, Schiff MH, Baumgartner SW, Tindall EA, Fleischmann RM, Bulpitt M, et al. Etanercept therapy in rheumatoid arthritis; a randomized, controlled trial. Ann Intern Med 1999;130:478-86.

44 Maini R, St Clair EW, Breedveld FC, Furst D, Kalden J, Weisman $M$, et al. Infliximab (chimeric anti-tumour necrosis factor alpha monoclonal antibody) versus placebo in rheumatoid arthritis patients receiving concomitant methotrexate: a randomised phase III trial. ATTRACT Study Group. Lancet 1999;354:1932-9.

45 Strand V, Cohen S, Schiff M, Weaver A, Fleischmann R, Cannon G, et al. Treatment of active rheumatoid arthritis with leflunomide compared with placebo and methotrexate. Arch Intern Med 1999;159:2542-50.

46 Sharp JT, Strand V, Leung H, Hurley F, Loew-Friedrich I. Treatment with leflunomide slows radiographic progression of rheumatoid arthritis: results from three randomized controlled trials of leflunomide in patients with active rheumatoid arthritis. Rheumatoid Arthritis Investigators Group. Arthritis Rheum 2000;43:495-505.

47 Kroger H, Arnala 1, Alhava EM. Effect of calcitonin on bone histomorphometry and bone metabolism in rheumatoid arthritis. Calcif Tissue Int 1992;50:11-13.

48 Ralston SH, Hacking L, Willocks L, Bruce F, Pitkeathly DA. Clinical, biochemical, and radiographic effects of aminohydroxypropylidene bisphosphonate treatme

49 Eggelmeijer F, Papapoulos SE, van Paassen HQ Dijkmans BAC, Valkema R, Westedt ML, et al. Increased bone mass with pamidronate treatment in rheumatoid arthritis; results of a three-year randomized double-blind trial. Arthritis Rheum 1996;39:396-402. 